ARchiWa - Kancelarie - ZBIORY

NR $5(7) / 2014$

\title{
IV Toruńskie Konfrontacje Archiwalne PT. „NOWA ARCHIWISTYKA - ARCHIWA I ARCHIWISTYKA W PÓŹNONOWOCZESNYM KONTEKŚCIE KULTUROWYM”
}

http://dx.doi.org/10.12775/AKZ.2014.010

7 ematem IV Toruńskich Konfrontacji Archiwalnych była „Nowa archiwistyka - archiwa i archiwistyka w późnonowoczesnym kontekście kulturowym”. Konferencja odbyła się 5-6 grudnia 2013 r. na Uniwersytecie Mikołaja Kopernika w Toruniu, w budynku Collegium Humanisticum przy ul. Bojarskiego 1. Organizatorami spotkania był Instytut Historii i Archiwistyki Uniwersytetu Mikołaja Kopernika w Toruniu; Archiwum Państwowe w Toruniu; Sekcja Edukacji Archiwalnej Stowarzyszenia Archiwistów Polskich; Instytut Historyczny Uniwersytetu Warszawskiego oraz Centrum Badań Antropologii Historii - Sekcja Naukowa Polskiego Towarzystwa Historycznego. Kierownikami naukowymi byli: Waldemar Chorążyczewski (Uniwersytet Mikołaja Kopernika) oraz Wojciech Piasek (Uniwersytet Mikołaja Kopernika), natomiast sekretarzami naukowymi Agnieszka Rosa (Uniwersytet Mikołaja Kopernika) i Piotr Bewicz (Uniwersytet Mikołaja Kopernika). Problematyka IV Konfrontacji obejmowała trzy główne bloki tematyczne: papier a cyfra, polityka i społeczeństwo oraz nowe źródła w nowych archiwach. W spotkaniu wzięło udział ponad 100 osób.

IV Konfrontacjom archiwalnym towarzyszyło otwarcie wystawy archiwalnej pt. Afirmacja życia. Szczęście i radość w zasobie Archiwum Państwowego $w$ Toruniu, które miało miejsce 4 grudnia 2013 roku w Archiwum Państwowym w Toruniu. Pomysłodawcą wystawy był Waldemar Chorążyczewski, natomiast jej wykonawcami: Dariusz Chyła (AP w Toruniu), Agnieszka Rosa 
i Piotr Bewicz. Przy jej tworzeniu pomagały także konserwatorki Archiwum Państwowego w Toruniu Marzena Kamińska i Joanna Jankowska. Na otwarcie przybyło 17 osób, w tym prof. Andrzej Tomczak. Wystawę otworzyła Dyrektor Archiwum Państwowego w Toruniu Beata Herdzin, która podkreśliła, że mamy do czynienia z przykładem dobrej współpracy Archiwum z instytucją naukową.

Konfrontacje poprzedzone zostały sympozjum Sekcji Edukacji Archiwalnej Stowarzyszenia Archiwistów Polskich pt. „Archiwistyka cyfrowa w edukacji archiwalnej. Pojęcia. Systemy. Metody i programy kształcenia. Pomoce dydaktyczne". Po jego zakończeniu rozpoczęły się obrady plenarne IV Toruńskich Konfrontacji Archiwalnych. Przybyłych przywitali Waldemar Chorążyczewski, Jarosław Kłaczkow (Uniwersytet Mikołaja Kopernika), Alicja Kulecka (Uniwersytet Warszawski) oraz Beata Herdzin (AP w Toruniu). Obrady poprowadziła Wiesława Kwiatkowska (Uniwersytet Mikołaja Kopernika).

Referat otwierający konferencję wygłosił Naczelny Dyrektor Archiwów Państwowych, Władysław Stępniak, który poruszył temat dostępu do zasobu archiwalnego wczoraj i dziś. Autor poświęcił dużo uwagi kwestii digitalizacji i cyfrowego udostępniania materiałów archiwalnych. Po tym wystąpieniu głos zabrała Wiesława Kwiatkowska, która wyraziła opinię, że dostęp do zasobów archiwalnych i uzyskanie pełnej informacji wymaga głębokiej wiedzy. Wskazała zagrożenie płynące z internetowych baz danych, które są przez niedoświadczonych użytkowników traktowanie jako podstawowe narzędzie wyszukiwania. Następnie swoje pytanie do referenta skierowała Anna Sobczak. Chciała się dowiedzieć, czy można ocenić, jak daleko mogą posunąć się archiwa przy otwieraniu się na „nowego użytkownika”. W odpowiedzi Władysław Stępniak dodał, że istotne znaczenie mogłoby mieć zapożyczenie praktyk stosowanych w Archiwum Narodowym w Wielkiej Brytanii, gdzie organizuje się dla użytkowników szkolenia z zakresu wyszukiwania. Z kolei według Pawła Weszpińskiego (Uniwersytet Warszawski) przy stwierdzeniu, że użytkownik nieprofesjonalny oczekuje szybkiego dostępu do informacji, zabrakło odniesienia do konkretnej sytuacji. Ponadto, odnosząc się do cyfryzacji, zwrócił uwagę na analogowy wymiar prac towarzyszący cyfryzacji. Nie zgodził się ze stwierdzeniem, że „w archiwach żyje się lepiej”, obecnie bowiem archiwiści mają coraz mniej czasu na pracę merytoryczną. Kolejny głos należał do Elżbiety Galik (AP we Wrocławiu), która zwróciła uwagę na potrzebę tworzenia odpowiednich pomocy wyszukiwawczych, bez których nie może powstać dobry system informacyjny. Przedstawiła także swoje obserwa- 
cje czeskiego i niemieckiego podejścia do udostępniania, z których wynika, że Czesi są mistrzami opracowania pomocy archiwalnych, a Niemcy dzięki swojej systematyczności osiągają imponujące wyniki. Ostatni głos w dyskusji zabrał Paweł Rodak (Instytut Kultury Polskiej). Dopytał on referenta o możliwość wprowadzenia zasad dotyczących ułatwienia dostępu i kopiowania, obowiązujących w archiwach państwowych, w np. archiwach literackich czy Bibliotece Narodowej. W odpowiedzi Władysław Stępniak wyjaśnił, że choć nie ma normatywu nakazującego takie działania, to owe zasady powinny być stosowane.

Jako drugi, w referacie pt. Podstawy teoretyczne „nowej archiwistyki”, Waldemar Chorążyczewski przedstawił swoją autorską propozycję nowej definicji przedmiotu archiwistyki, jaką ma być dziedzina archiwalna. Po referacie nastąpiła ożywiona dyskusja. Pierwsza głos zabrała Elżbieta Galik, której nie spodobały się założenia „nowej archiwistyki”. Przedstawiła postulat szerszej współpracy teoretyków i praktyków dziedziny archiwalnej oraz wskazała konieczność określenia kryteriów wartościowania. Następnie Władysław Stępniak stwierdził, że nie widzi jakiś nowych elementów w przedstawionych podstawach teoretycznych „nowej archiwistyki”. Tym niemniej podkreślił, że nie jest przeciwny takiemu poglądowi, a zwłaszcza fundamentalnemu czynnikowi antropologicznemu. Z kolei Alicja Kulecka stwierdziła, że choć praktyka jest bardzo istotna, to nie możemy pomijać rozwoju teoretycznych rozważań, które tworzą nowe pola badawcze. Waldemar Chorążyczewski stwierdził, że za mało jest badań czysto naukowych, a za dużo rozważań opartych na osobistych przemyśleniach.

Kolejną referentką była Olga Ivanova, reprezentująca białoruską archiwistykę. Scharakteryzowała rodzimy system archiwalny, przedstawiła historię powstania „tradycyjnych” archiwów, przemiany na Białorusi w latach 90., zasady stworzenia „nowych” archiwów oraz główne cechy współczesnego projektowania archiwów. Dyskusję rozpoczął Władysław Stępniak, który przedstawił swoją refleksję na temat niedawnej wizyty w nowo wybudowanym archiwum otomańskim w Stambule. Dostrzegł tam tendencję odwrotną do tej przedstawionej w referacie. Wskazał jednocześnie zagrożenie płynące z mnożenia archiwów wyodrębnionych.

Następny referat pt. Algorytm archiwalnego myślenia i jego realizatorzy. Refleksja ogólna i szczególna oparta na doświadczeniach pracy archiwalnej i muzealnej ze zbiorami kartograficznymi wygłosił Paweł E. Weszpiński. Przedstawił on główną hipotezę, zgodnie z którą myślenie archiwalne nie jest przynależ- 
ne tylko do archiwów. Dyskusję rozpoczęła Alicja Kulecka, odnosząc się do dziedzictwa kulturalnego. Zaznaczyła, że archiwa gromadzą dokumentację urzędową, biblioteki druki, a muzea obiekty materialne, oraz wyraziła opinię, że wywracanie tego porządku jest niebezpieczne. Maciej Jasiński (Archiwum m.st. Warszawy) odniósł się natomiast do podejmowanego wcześniej wątku rozdziału archiwów, bibliotek i muzeów. Zwrócił on uwagę na to, że instytucje różnego typu wytwarzają poza materiałami archiwalnymi materiały, które można określić jako „dokumentacja nietypowa”, których nie mogą oddać ani do bibliotek, ani do muzeów, mogą je za to przekazać swoim archiwom zakładowym. Głos zabrał także Andrzej Tomczak (Uniwersytet Mikołaja Kopernika), który podkreślił, że jest różnica pomiędzy materiałami archiwalnymi, bibliotecznymi i muzealnymi - w każdej instytucji można jednak znaleźć materiały przynależne do pozostałych.

Po przerwie prowadzenie panelu objął Paweł Rodak (Uniwersytet Warszawski). Pierwszy referat pt. Archiwum jako teren dziatalności spoteczno-badawczej wygłosiła Inga Kuźma (Uniwersytet Łódzki, Archiwum Etnologiczne). Autorka odniosła się do kwestii rozpowszechniania idei archiwum, jako szczególnego sposobu dokumentowania przeszłości. Dyskusję rozpoczęto od zadania autorce pytania, czy można skorzystać z zasobu Archiwum Etnograficznego? Odpowiedź była twierdząca. Kolejną osobą, która podzieliła się swoimi przemyśleniami, był Tomasz Czarnota (Uniwersytet Marii Curie-Skłodowskiej w Lublinie). Ostatni głos w tej dyskusji należał do Alicji Kuleckiej, wg której historyk będzie musiał poddać materiały krytyce, w związku z czym omawiane archiwum jest archiwum naukowym według projektu.

Kolejnym mówcą była Katarzyna Majbroda (Uniwersytet Adama Mickiewicza w Poznaniu). Zaprezentowała ona referat pt. Archiwum jako metafora epistemologiczna $w$ antropologii spoteczno-kulturowej. W swoim wystąpieniu autorka poruszyła kwestię pojęcia archiwum jako metafory poznawczej fundowanej na kategorii tekstu, przy czym tekst uznała jako warsztat konstruowania wiedzy i nauki. W dyskusji do kwestii wielokontekstowości odnieśli się Paweł Rodak, Elżbieta Galik, Wojciech Piasek oraz Wiesława Kwiatkowska.

Następny referat pt. Nowa archiwistyka - w stronę kulturowej teorii archiwum $i$ archiwaliów wygłosił Wojciech Piasek. Autor przedstawił zgromadzonym punkt widzenia historyka na kwestie archiwalne. Zdaniem Elżbiety Galik referent przedstawił nowe spojrzenie dla praktyk archiwalnych, ukazując istotę rzeczy, którą i ona starała się wyrazić. 
Po przerwie prowadzenie obrad objął Robert Degen (Uniwersytet Mikołaja Kopernika). Pierwszy referat w tej części należał do Wojciecha Woźniaka, który omówił temat Cyfrowe średniowiecze czy opowieści o smokach - o szansach $i$ zagrożeniach epoki cyfrowej $w$ archiwach. Autor zwrócił uwagę, że dokument ulega zniszczeniu, gdy niszczony jest nośnik. Wskazał, zasady ochrony nośników informatycznych i zabezpieczania danych. Odwołał się także do zarzutu wysokich kosztów przechowywania danych cyfrowych, starając się wykazać ich bezzasadność. Dyskusję rozpoczęła Anna Sobczak, która chciała się dowiedzieć, czy jest szansa na ustalenie formatów zapisu dla danych urzędowych. W odpowiedzi usłyszała, że nie ma standardów odnośnie do formatów, które mają być wymagane przez archiwum. W dyskusję włączył się także Maciej Jasiński, który postulował, aby dokument papierowy pozostał dokumentem podstawowym, zabezpieczenie tradycyjne jest bowiem najlepsze. W dyskusji wzięli udział także Alicja Kulecka i Paweł Weszpiński.

Następnie Tomasz Czarnota wystąpił z referatem pt. Problematyka dziatalności dokumentacyjnej wspótczesnych archiwów. W swojej refleksji stwierdził, że obecnie działalność dokumentacyjna odbywa się w archiwach państwowych na marginesie podstawowej działalności. Przedostatnie wystąpienie w tej części należało do Pawła Guta (AP w Szczecinie). W swoim referacie pt. Państwo polskie $w$ dziatalności naukowej i popularyzatorskiej archiwów przypomniał m.in. duże wystawy zorganizowane przez Archiwum Państwowe w Szczecinie. Autor uznał że, działalność archiwów państwowych po 1945 r. była z jednej strony częściowo wykorzystywana do legitymizacji władzy, ale z drugiej strony pozwalała na funkcjonowanie archiwów w świadomości społecznej. Dyskusję rozpoczął Paweł Weszpiński, według którego niestety praca naukowa nie wszędzie jest należycie realizowana. Jako kolejna głos zabrała Elżbieta Galik, która nawiązała do wystąpienia Wojciecha Piaska i stwierdziła, że archiwum nie powinno być miejscem legitymizacji władzy powinno być niezależne.

Ostatni referat w tej części wygłosił Adam Grzegorz Dąbrowski (Archiwum Akt Nowych). Jego wystąpienie pt. A jednak dokument papierowy, czyli spojrzenie archiwisty - tradycjonalisty stanowiło refleksję na temat baz danych i problemów, które pojawiały się przy pierwszych ich wersjach. Dyskusję rozpoczęła Hanna Staszewska (AP w Poznaniu), następnie włączyli się do niej Maciej Jasiński, Adam Korczyński (Polska Akademia Umiejętności) i Tomasza Czarnota. Na zakończenie Waldemar Chorążyczewski stwierdził, że cyfryzacja nastąpi, ale zawsze pozostanie sfera „papierowej” alternatywy. 
Obrady zakończył Waldemar Chorążyczewski, zapraszając wszystkich uczestników konferencji na uroczysty bankiet, który odbył się w Bibliotece Głównej Uniwersytetu Mikołaja Kopernika.

Drugiego dnia obrady podzielone były na dwie części, pierwsza z nich składała się z trzech paneli tematycznych: papier a cyfra, polityka i społeczeństwo oraz nowe źródła w nowych archiwach. Po przerwie obiadowej uczestnicy Konfrontacji wrócili na część plenarną, podczas której moderatorzy przedstawili sprawozdania z paneli oraz wygłoszono trzy ostatnie referaty.

Wystąienie Macieja Zdunka (Narodowe Archiwum Cyfrowe) pt. Archiwa miejscem spotkań rozpoczęło obrady panelu „Papier a cyfra”. Referent omówił budowę społeczeństwa informacyjnego i możliwości pozyskania przez archiwa szerszego grona użytkowników. Marcin Wilkowski (Portal Historia i Media) w referacie pt. O potrzebie edukacji $w$ zakresie osobistej archiwistyki cyfrowej (personal digital archiving) przedstawił problem cyfrowych zbiorów osobistych. Z kolei Anna Sobczak w referacie Internet jako globalne archiwum spoteczne - rozważania na temat roli internetu $w$ dokumentowaniu dziejów ludzkości przedstawiła internet jako rodzaj archiwum społecznego, z dostępem i możliwością zmian przez wszystkich użytkowników. Takie ujęcie tematu wywołało ożywioną dyskusję. Ostatni, w pierwszej części panelu, referat pt. Stare źródta $w$ nowych archiwach. O repozytorium cyfrowym zbioru „Robotnicy w XIX i XX wieku” wygłosiła Grażyna Karpińska (Uniwersytet Łódzki). Wystąpienie oparte zostało na doświadczeniach autorki w kierowaniu projektem polegającym na tworzeniu cyfrowego repozytorium dla ponad 10 tys. fotografii nadesłanych na konkurs, ogłoszony w 1985 r. Drugą część panelu rozpoczął Henryk Niestrój (Narodowe Archiwum Cyfrowe). Podczas wystąpienia pt. Retrokonwersja pomocy archiwalnych, mówił o retrokonwersji jako zjawisku polegającym na przekształcaniu materiałów z wersji papierowej w struktury bazodanowe posiadające możliwość przeszukiwania. Podkreślał, że w działaniach mających na celu doprowadzenie do digitalizacji archiwaliów najważniejsze jest ich wcześniejsze zewidencjonowanie. W trakcie dyskusji po referacie padło kilka pytań i stwierdzeń ze strony słuchaczy, w tym Anny Sobczak i Hanny Staszewskiej. Ksiądz Roman Majka (Archiwum Zgromadzenia Świętego Michała Archanioła) w referacie pt. Digitalizacja zasobu archiwów zakonnych $w$ ujęciu transdyscyplinarnym z ukierunkowaniem interdyscyplinarności informował, iż istnieje potrzeba podjęcia nowych strategii w digitalizacji archiwów zakonnych, a sieć internetowa staje się obszarem depozytu materiałów tych archiwów. Referat pt. Zasób i kierunki roz- 
woju Fonoteki Lanckorońskich PAU a wspótczesne ujęcie „archiwum fotograficznego" wygłosił Adam Korczyński (Polska Akademia Umiejętności). Na początku omówił pojęcie archiwum fotograficznego, a następnie przedstawił historię Fonoteki Lanckorońskich, wielkość jej zbiorów, miejsca przechowywania i jej rolę jako źródła historycznego. Maciej Zdunek zadał pytanie m.in. o wielkość zbioru, który liczył ok. 80-100 tys. jednostek, a obecnie ponad 40 tys. Katarzyna Kalisz (Narodowe Archiwum Cyfrowe) zapytała, czy jest to kolekcja, czy są to również materiały wytworzone przez rodzinę Lanckorońskich. Referent w odpowiedzi stwierdził, iż w zbiorach znajdują się zdjęcia przedstawiające Karolinę Lanckorońską, a także spuścizna rękopiśmienna Karola Lanckorońskiego. Robert Górski (NDAP) polemizował natomiast ze stosowanym przez autora pojęciem „archiwum fotograficzne”. W kolejnym wystąpieniu, pt. Kulturowy kontekst archiwów filmowych, Magdalena Niedźwiedzka przedstawiła w krótkim ujęciu historię kina oraz zarysowała problem zrodzenia się potrzeby archiwizacji materiałów filmowych.

Panel na temat Polityka i spoteczeństwo poprowadził Paweł Gut. Pierwszy referat pt. Archiwa wyodrębnione w państwie demokratycznym wygłosił Rafał Galuba (Uniwersytet Adama Mickiewicza w Poznaniu). Wskazał on na trudność zdefiniowania pojęcia „państwa demokratycznego”. Robert Kubaś (Archiwum Wyodrębnione Senatu), stwierdził, że jego instytucja jest otwarta na użytkowników, którzy prowadzą badania naukowe. W dyskusję włączyły się również Alicja Kulecka oraz Halina Robótka. W referacie pt. Wspótczesne wyzwania dla prawnej regulacji dziatalności archiwalnej Marek Konstankiewicz zaprezentował tezę, że polskie prawo archiwalne wymaga zmian, które doprowadzą do harmonizacji przepisów. Wskazał kierunek istotnych przemian oraz płynące z nich zagrożenia. W dyskusję zaangażowali się Adam Dąbrowski (Archiwum Akt Nowych), Wiesława Kwiatkowska, Jerzy Bednarek (Instytut Pamięci Narodowej) oraz Rafał Galuba. Kolejny referat pt. Archiwa powstania styczniowego wygłosiła Alicja Kulecka. W swoim wystąpieniu przedstawiła drogi proweniencji archiwaliów powstających w wyniku ważnych wydarzeń politycznych. Ostatni referat w tej części wygłosiła Elżbieta Galik. Podjęła próbę zdefiniowania pojęcia „kultury” oraz omówienia tożsamości dyscypliny archiwalnej. Ponadto wskazała na interdyscyplinarny charakter archiwistyki, podkreślając, że w tej szerokiej przestrzeni nie można zatracić istoty dziedziny archiwalnej. W sprawie zamętu pojęciowego wypowiedziała się Alicja Kulecka, wskazując, iż bierze się on z różnych nurtów dyskusji. Z kolei Wiesława Kwiatkowska podkreśliła, że funkcje archiwum są stałe. Do 
dyskusji włączyła się także Halina Robótka, która chciała wiedzieć, jak w ocenie pani Galik wypadają propozycje autora książki Problemy i metody badawcze archiwistyki, Bohdana Ryszewskiego.

Drugą część panelu „Polityka i społeczeństwo” otworzył referat Marleny Jabłońskiej (Uniwersytet Mikołaja Kopernika) pt. W poszukiwaniu ztotego środka. Uwag kilka na temat wewnętrznej i publicznej pracy archiwów. Autorka starała się ukazać możliwości, jakie niosłoby ze sobą wprowadzenie działań public relations i przedsięwzięć marketingowych dla funkcjonowania archiwów, a przede wszystkim zmiany ich wizerunku. W ożywionej dyskusji wzięli udział m.in. Paweł Gut, Eugeniusz Borodij (AP w Bydgoszczy) oraz Violetta Urbaniak (AP m.st. Warszawy). Hubert Mazur (AP w Kielcach) wystąpieniem pt. Między dydaktyką a archiwistyka. Interdyscyplinarność archiwistyki w kontekście edukacyjnej funkcji archiwów starał się odpowiedzieć na szereg nurtujących go pytań. Próbował wyjaśnić złożoność problematyki funkcji edukacyjnej archiwów. Rafał Galuba (Uniwersytet im. Adama Mickiewicza w Poznaniu) dodał, że w polskich warunkach nie można nakładać na archiwistów nowych obowiązków, do których nie są przygotowani, zarówno pod względem metodologii, jak i wykształcenia. Z kolei Violetta Urbaniak stwierdziła, że to, co młodzież czy dzieci w archiwum zainteresowałoby, to wygląd magazynu, specyficzny zapach, duże tomy na regałach czy ciekawe zdjęcia. Andrzej Tomczak stwierdził, iż ma wrażenie, jakby w dyskusji głos zabierały osoby myślące jak pod koniec lat 50., kiedy władze zaproponowały, aby archiwa prowadziły działalność kulturalno-oświatową. Kolejny referat, pt. Archiwa a inicjatywy kulturalne czynnych partii politycznych - czy możliwa jest wspótpraca?, wygłosił Tomasz Matuszak (AP w Piotrkowie Trybunalskim). Autor omówił, z jakimi instytucjami archiwa państwowe mają szansę i powinny współorganizować wszelkie inicjatywy oraz jakie mogą przyjmować patronaty. Przedstawił również swój pogląd na granice bezstronności i obiektywizmu, w głównej mierze w oparciu o partie polityczne czy środowiska religijne. Temat zmotywował do dyskusji m.in. Roberta Kubasia, Eugeniusza Borodija, Rafała Galubę oraz Joannę Chojecka (AP w Koszalinie).

Panel „Nowe źródła w nowych archiwach” rozpoczęło wystąpienie Pawta Rodaka pt. Archiwa prywatne, archiwa rodzinne, archiwa stowarzyszeniowe. Kilka uwag o znaczeniu archiwów pozainstytucjonalnych i sposobach ich instytucjonalizacji. Podczas swojego referatu omówił archiwa autobiograficzne, prywatne i rodzinne. Katarzyna Ziętal (Ośrodek KARTA) dopytała, czy autor posiada informacje na temat współpracy omawianych stowarzyszeń z in- 
stytucjami państwowymi. W odpowiedzi referent poinformował, że nie ma informacji na temat współpracy w zakresie opracowania, posiada je jedynie w kwestii pozyskania środków przez interesujące go stowarzyszenia we Francji. Kolejno w dyskusji wzięli udział Wojciech Piasek i Andrzej Tomczak. Katarzyna Ziętal i Sylwia Kopeć (Ośrodek KARTA) w referacie Czy archiwum spoteczne to jeszcze archiwum? przytoczyły przykłady zbiorów archiwów społecznych przechowywanych w Ośrodku KARTA. Pierwsza głos w dyskusji zabrała Magdalena Wiśniewska (Uniwersytet Mikołaja Kopernika w Toruniu), stwierdzając, że archiwa stowarzyszeń wchodzą w skład państwowego zasobu ewidencjonowanego i archiwalia po likwidacji tych inicjatyw powinny trafiać do najbliższego archiwum państwowego. Tomasz Czarnota stwierdził, iż zapis ustawy mówiący o przejęciu tych archiwaliów przez archiwa państwowe jest niekonstytucyjny, natomiast Andrzej Tomczak przypomniał, że dobrze zorganizowane stowarzyszenia mają w swoich statutach informacje, że po ustaniu ich działalności cały zasób przejmie określone archiwum państwowe lub inna instytucja. Swoje zdanie wyraziła także Violetta Urbaniak. Anna Żeglińska (Uniwersytet Warmińsko-Mazurski w Olsztynie) przedstawiła referat pt. Koncepcja archiwum dla zasobu oral history, w którym omówiła koncepcję zdobywania przez archiwistów państwowych materiałów historii mówionej, które uzupełniałyby zespoły archiwalne. Dyskusję rozpoczęła archiwistka z Białorusi, następnie dołączyli do niej Andrzej Tomczak (stwierdził, że przedstawiona koncepcja jest bardzo idealistyczna, a mało realna), Paweł Rodak oraz Katarzyna Ziętal. Następnie Urszula Kowalczyk (AP w Warszawie) odczytała tekst pt. „Dla Polaków na wychodźstwie wykonujecie $w$ piśmiennictwie prace bardzo cenna" - korespondencja administracyjna $w z a-$ sobie Instytutu Literackiego w Maisons-Laffitte jako świadectwo udziatu wydawnictwa $w$ ksztattowaniu myślenia politycznego emigracji, w którym scharakteryzowała korespondencję administracyjną Instytutu Literackiego z twórcami myśli emigracyjnej. Andrzej Tomczak podziękował referentce za przypomnienie wpływu Giedroycia na kulturę. Na pytanie Pawła Rodaka o to, kto zajmował się prowadzeniem tej korespondencji, prelegentka poinformowała, że był to na ogół Henryk, brat Jerzego Giedroycia. Tomasz Czarnota dodał, że z jego badań wynika, iż nie było dokładnego podziału, kto miał zajmować się omawianą korespondencją.

Drugą część obrad rozpoczęło wystąpienie Adama Koli (Uniwersytet Mikołaja Kopernika w Toruniu) pt. Materialność pisarstwa translingwalnego. Literaturoznawca w archiwum, w którym przedstawiono osobę Romana Jakob- 
sona oraz jego archiwum. Pierwszy głos w dyskusji zabrał Paweł Rodak, który zapytał, czy zjawisko przechodzenia z języka w język występuje również w korespondencji bądź dokumentacji prywatnej wspomnianych osób. Magdalena Wiśniewska zaproponowała referentowi zapoznanie się ze spuścizną po prof. Stanisławie Gorgolewskim. W dyskusji wzięli udział także Wojciech Piasek i Sciapan Zacharkiewicz (Białoruski Uniwersytet Państwowy w Mińsku). W swoim wystąpieniu, pt. Autoportret z Klio. Essais d'ego-historie kontra „autohistoria” Arona Guriewicza, Anna Brzezińska (Uniwersytet Łódzki) dokonała analizy biografii historyków z perspektywy historyka historiografii. Rozpoczynając dyskusję, Wojciech Piasek odniósł się do autobiografii Karola Górskiego. Swoją opinię wyraził także Adam Kola. Następnie Aliaksandr Bialiauski oraz Sciapan Zacharkiewicz omówili Heurystyczna role archiwum $w$ kręgu biatoruskich historyków profesjonalistów. Autorzy uznali biblioteki i archiwalia za ważne narzędzie dla zrozumienia przeszłości, ale również sakralizacji wizerunku i pracy historyka. Adam Kola z życzliwością odniósł się do referatu. Stwierdził, że praktykę akademicką warto opisywać w kategoriach przejścia czy wtajemniczenia. Katarzyna Majbroda zauważyła, że takie praktyki są potrzebne, ale poddała w wątpliwości, czy inne dziedziny nauki są przygotowane na autorefleksję. Referat Agnieszki Zabielskiej pt. Archiwum Matopolskiego Centrum Doskonalenia Nauczycieli jako źródto do badań nad historia edukacji nauczycieli w Polsce zamykał panel. Referentka scharakteryzowała zasób omawianego przez nią archiwum oraz omówiła dotychczas przeprowadzone badania i ich wyniki. Dyskusję otworzył Tomasz Czarnota, który zauważył, że zasób archiwów zakładowych to późniejszy zasób archiwów państwowych.

Sesję plenerową otworzył referat Piotra Bewicza, który próbował opisać archiwistykę nierozliczoną z postmodernizmem. Zauważył, że emocje, które podczas pracy w archiwum dotykają archiwistów i użytkowników, stają się nowym obiektem zainteresowań badaczy. Dyskusję rozpoczął Waldemar Chorążyczewski, który stwierdził, że omawiani pisarze skupiali się na doświadczeniu tego, kto przychodzi do archiwum z zewnątrz, czyli użytkownika. Do zmian, które przyniosła rewolucja przemysłowa, w interesujący sposób odniosła się Anna Brzezińska. Po jej słowach Waldemar Chorążyczewski dodał, że ciekawe może być badanie, na ile mówienie o doświadczeniu archiwalnym przez pisarzy, wynika z informacji zebranych od innych osób, a na ile z osobistych doświadczeń. 
Magdalena Wiśniewska wygłosiła referat pt. Archiwum spoteczne - nowy rodzaj archiwum. Podczas wystąpienia omówiła, przyczyny powstawania i ciągłego działania archiwów społecznych. Referat został życzliwie przyjęty przez słuchaczy. W dyskusji wzięła udział m.in. Katarzyna Ziętal, która podała, gdzie można znaleźć archiwa klubów sportowych. Z kolei Waldemar Chorążyczewski zapytał, czy autorka zna przykłady efemeryczności archiwów, czy ktoś je potem faktycznie przejmuje. Wiśniewska stwierdziła, że archiwa te nie są tak trwałe jak państwowe, ale większość instytucji gromadzących zasób społeczny chce przekazywać swoje dokumenty do Ośrodka KARTA. W dyskusję włączyła się także Anna Sobczak, zainteresowana innymi inicjatywami dotyczącymi archiwistyki społecznej. Jako ostatni głos zabrał Robert Kubaś, który poinformował zebranych o rozpoczęciu zbierania przez jego instytucję archiwów przełomu. Ostatni referat wygłosił Hadrian Ciechanowski. W wystąpieniu pt. Archiwum jako miejsce zapomnienia uznał archiwa za miejsca pamięci. Wyjaśnił tezę, że pamięć nie istnieje bez zapomnienia. Waldemar Chorążyczewski stwierdził, że postawiony problem jest trudny do ujęcia, uznał także, że łatwiejsze byłoby ujęcie z perspektywy zapomnienia przez niszczenie. Wojciech Piasek dodał, że problem brakowania wynika z naszej potrzeby zapamiętania wszystkiego. Anna Sobczak zapytała, dlaczego nie archiwizować wielu rzeczy, skoro nowe technologie nam na to pozwalają.

Podsumowania konferencji dokonał Wojciech Piasek, który skonfrontował swoje wyobrażenie archiwistyki sprzed konferencji i swojego referatu z tym, czego dowiedział się podczas spotkania. Wyraził swoje zadowolenie z tego, że spotkał wielu archiwistów teoretyków myślących o swojej roli, zwłaszcza w kontekście kultury. Jako historyk pogratulował archiwistom autorefleksji nad swoją pracą i rolą w społeczeństwie, czego często brakuje innym zawodom. Konfrontacje zakończyły się sukcesem, a ich uczestnicy wysoko ocenili ich wartość merytoryczną.

Agnieszka Zasada, Mateusz Zmudzinski (Uniwersytet Mikołaja Kopernika w Toruniu) 